\title{
Resource Use Efficiency in Organic Vegetable Production: A Case Study of Manzini Region, Swaziland
}

\author{
Dumsile Dlamini F \\ University of Swaziland, Department of Economics \\ Kwaluseni Campus, Private Bag 4, Kwaluseni M201. Swaziland \\ Tel: 268-2517-0408 \\ Mukole Kongolo (Corresponding author) \\ University of Swaziland, Department of Economics \\ Kwaluseni Campus, Private Bag 4, Kwaluseni, M201, Swaziland \\ Tel: 268-2517-0233Ｅ-mail: gilkoka8@gmail.com
}

Received: May 28, 2014 Accepted: June 9, 2014

doi:10.5296/jas.v2i2.5958 URL: http://dx.doi.org/10.5296/jas.v2i2.5958

\begin{abstract}
This study investigated the efficient use of resources in the production of organic vegetables, namely: beetroot, cabbage, carrot, pepper, spinach and tomatoes. The findings indicated that land, labour, organic manure, seeds, soil preparation, age; children, education level and farm legal entity all had significant effect in organic vegetables production in the region. The use of inputs in the production of the vegetables showed increasing returns to scale. As a result of this, the study suggested that in order for farmers to produce efficiently; all inputs that were significant in the production of the vegetables needed to be doubled in order to double the output.
\end{abstract}

Keywords: Efficient resource use, Organic vegetable, Organic farming, Agricultural production, Manzini 


\section{Introduction}

Organic farming is a farming system that does not use synthetic chemicals or genetic alteration. The farming process relies on natural elements, repellents, and hard manual labor. The crops yielded are small, but yield a variety of plants. This system promotes healthy living and a better ecosystem for today's and tomorrow's world, while conventional farming methods send the message of greed and mass production. Organic farming is a lot healthier because of the absence of chemicals and genetic alteration (Avery, 2006; Studymode, 2011). The fruits and vegetables grown at these all natural farms are treated with care and are held to strict laws to make sure the food is safe for the consumer and the farmer. Fruits and vegetables that were grown organically have more nutrients and higher levels of vitamins (Soil Association, 2008). There are, as with sustainable agriculture, a variety of definitions of organic farming. It is referred to as a holistic view of agriculture that aims to reflect the profound interrelationship that exists between farm biota, its production and the overall environment.

Organic farming does not simply refer to the use of living materials, but emphasises the concept of 'wholeness' (Feber et al. (1997), implying the "systematic connexion or co-ordination of parts in one whole (Rigby and Cacere, 2001). Organic farming holds an increasingly important position in today's agriculture. Hardly any discussion about the future of modern agriculture is made without taking organic farming into consideration (Niemeyer \& Lombard, 2003). The pattern of world food consumption has changed over the last two decades towards a greater demand for quality attributes. Among the reasons for this shift are: concern for health and nutrition (Tregear, Dent \& McGregor, 1994), eroded confidence in the conventional food industry (Alvensleben \& Attmann, 1987), concern for the environment (Wandel \& Bugge, 1997), concern with the chemicals in conventional food products (Dixon \& Holmes, 1987), improved taste and flavour of organics products (Davies, Titterington \& Cochrane, 1995; Feber et al.1998), and animal welfare (Hutchins \& Greenhalgh, 1997). Organic farming has been the subject of debate, as it goes to the heart of the issue of whether incentives and technical support for organic sector expansion are needed and even whether widespread organic agriculture would be capable of producing sufficient food (Francis and van Wart, 2009; Avery \& Avery, 2004).

Opponents of organic agriculture have argued that this system necessarily results in lower productivity than conventional agriculture, resulting in more land needed for biodiversity being converted to produce food. However, without the knowledge of the factors affecting productivity and efficiency, the premises of these claims - that organic agriculture is necessarily lower yielding - cannot be proposed (Lohr \& Park, 2004). As indicated by Lohr and Park (2004), interest in organic production efficiency has focused on comparisons with non-organic agriculture. However, such comparison fails to address the cause of differences in efficient use of inputs within the organic sector, which tends to hinder yield improvement and competitiveness of organic food producers in the domestic and global markets. The organic food market is supported by consumers in nearly every developed country in the world. Organic foods are distinguished from non-organic foods by the methods used in their production and processing, rather than by observable or testable characteristics. 
Although there is no single international organic production regulation, all generally accepted organic rules prohibit use of synthetic fertilizers, pesticides, growth regulators and livestock feed additives and require long term soil management, emphasis on animal welfare, and extensive record keeping and planning. Although labour, farm size, crop mix and soil quality have been identified as factors in organic farm productivity, there has been few formal analysis to determine the efficient use of these inputs that can result in higher yields. This study therefore seeks to use the Cobb- Douglas production function (Gujarati, 2006) to assess the efficient use of resources in organic vegetable production as well as to identify key production factors in the organic farming system.

\subsection{Importance of Organic Farming}

The roots of organic farming go right back to the early 20th century. Organic farming arises from a philosophical and practical basis, which have led to the development of a variety of alternative methods of agricultural production worldwide (Herrera-Estrella and Alvarez-Morales, 2001). This is one of the reasons why people have misconceptions of what organic farming actually is (Writework, 2006). Organic farming helped on the food security and economy in a numerous immeasurable ways that are not imaginable. Firstly, Organic farming is seems to be eco-friendly or environmentally friendly. Organic farming promotes biodiversity sustainability. It helps contributes to puts back to earth what Mother Nature deserve and maintain the peace of Mother Nature. Substantially organic farming has supported the levels of biodiversity, it proves that levels of abundance and diversity of wild life (Soil Association, 2000). According to Bord Bia (2012) "Organic agriculture includes all agricultural systems that promote the environmentally, socially and economically sound production of food and fibres. These systems take local soil fertility as a key of successful production. By respecting the natural capacity of plants, animals and the landscape, it aims to optimise quality in all aspects (Lotter et al. 2003).

Organic agriculture builds the health of the soil, providing the foundation for healthy crops and a livelihood for good stewards of the land. In order to be certified organic, crops must be grown on land free of prohibited substances for at least three years prior to harvest (Organic Trade Association, 2008). Organic farming is the process by which agriculturists create \& cultivate vegetables, dairy products, grains, meat $\&$ fruits. The process of organic farming has been brought in to use to preserve water $\&$ soil $\&$ also to reduce the pollution that can be caused because of faming. Organic farming does not involve any of the conventional farming methods to keep away from the diseases that can occur in the livestock $\&$ to control pests in the vegetable or fruit farming $\&$ for that matter even fertilizer. Organic farming puts in to use the natural methods to keep away from any harm to the farming. The organic farming differs from the conventional farming in a lot of ways. In conventional farming, synthetic chemicals are made use of to increase the growth of cultivation. However, in organic farming it is preferable to make use of organic wastes \& compost in the kind of fertilizers, which may finish up in increasing the nutrients supplied to the plants (Frieben \& Köpke, 1995).

Undertaking this study will help to identify the strengths and weaknesses of the organic farming sector, which will help policy-makers, organic farming associations and organic producers in general to design appropriate policy measures and programmes with view of 
uplifting and improving the competitiveness of the organic farming sector Magkos et al. 2006). Judging from the significance of vegetables (beetroot, cabbage, carrot, pepper, spinach and tomato) in the daily diet of the average household in South Africa (Niemeyer \& Lombard. 2003), it is clear that effort to promote organic vegetables farming could be invalidated if individual farms do not reach adequate efficient use of inputs. To deal with these deficiencies, one needs to know or have current levels/measures of efficiency use of resources or inputs. In spite of the relevance of these measures, literature on the performance of organic farming is still insignificant, primarily due the little attention given to the efficient use of inputs.

\subsection{Objective}

The main objective of the study was to measure the efficient use of resources utilised in organic vegetable production following beetroot, cabbage, carrot, pepper, spinach and tomatoes vegetables production as a case study. Specifically, the study intended to:

- determine the efficient use of resources by organic food producers in the region; and

- identify the key socio-economic factors and management practices influencing increasing returns to scale;

\subsection{Research Question}

The three main research questions addressed in this study include:

- What are the most important efficient resources used in organic farming?

- How successful organic farms achieved returns to scale?

- How to reduce the percentage of farms that have failed as a result of decreasing returns to scale?

\section{Research Methodology}

\subsection{The Study Area}

The study was conducted in Manzini and surrounding areas of the region. The region forms the central part of the country, covering the Highveld, middleveld and down to the lowveld. Its highland areas include the forestry town of Mhlambanyatsi and the beautiful Ngwempisi Gorge cutting through the Ntfungulu Hills (World Atlas, 2014). Manzini region is located in the center-west of the country, and it has an area of about $4,093.59 \mathrm{~km}^{2}$. The region has a population of about 319,530, and is divided into 9 locations (CSO, 2007). Swaziland's diverse agricultural activities include sugar, citrus fruit, maize and other crops, cotton, forestry and livestock. Chickens, goats, sheep and cattle are raised for meat production (Swaziland Business Year Book, 2002). Small-scale farmers dominate the production of the food crops. Women generally handle food production, transport to markets, and sale (Sassou et al. 2011; SADC,2013). Women continue to play a critical role in agricultural development, hence, understanding their transport patterns would be the first step to reduce their onerous task (Calvo 1994). 


\subsection{Data Collection}

The research design for this study included a descriptive research design applying a quantitative and qualitative approach. The research used both secondary and primary data. Secondary data was gathered from various official reports while primary data was collected from a cross-sectional survey of organic food producers in the region. Assistance from the Ministry of Agriculture was sought to some extent. A simple random sampling method was used to select organic vegetable producers, participants. As a result, 60 participants were selected across the region, giving a selection rate of about $76.3 \%$.

\subsection{Model and Estimation}

A production function used in this study follows Anim (2010). It is the one frequently described in economic theory a Cobb-Douglas production function (Wikipedia; Egwald Economics). The Cobb-Douglas production function, in its stochastic form, may be expressed (Gujarati 1998):

$$
Y_{i}=\beta_{1} X^{\beta}{ }_{2 i}^{2} X^{\beta}{ }_{3 i}^{3} e^{u i}
$$

Where $\mathrm{Y}=$ output

$\mathrm{X}_{2}=$ Labour input

$\mathrm{X}_{3}=$ Capital input

$u=$ stochastic disturbance term

$e=$ base of natural logarithm

From the above general equation it is clear that the relationship between the output and the two inputs is nonlinear. However, if we log-transform the above model, we obtain

$$
\ln Y_{i}=\ln \beta_{1}+\beta_{2} \ln X_{2 i}+\beta_{3} \ln X_{3 i}+u_{i}=\beta_{o}+\beta_{2} \ln X_{2 i}+\beta_{3} \ln X_{3 i}+u_{i}
$$

where $\beta_{\mathrm{o}}=\ln \beta_{1}$

Model (2) is linear in the parameters $\beta_{o}, \beta_{2}$, and $\beta_{3}$ is therefore a linear regression model. It is nonlinear in the variables $\mathrm{Y}$ and $\mathrm{X}$ but it is linear in the logs of these variables. In the CobbDouglas production function $\beta_{1}$ is the (partial) elasticity of output with respect to the land input, that is, it measures the percentage change in output for, say, a one percentage change in the land input, holding the labour input constant. The sum of $\left(\beta_{1}+\beta_{2}\right)$ gives information about the efficient use of inputs, that is, the response of output to a proportionate change in the inputs. If the sum was less than 1 , there would be decreasing returns to scale, doubling the inputs would less than double the output. Lastly, if the sum was greater than 1, there would be increasing returns to scales, doubling the inputs will more than double the output, meaning the production of the output Y was efficient (Gujarati, 2006; Anim, 2010). Following Anim (2010), the Cobb-Douglas production function, in its linear form, used in this study was expressed as given in equation (3): 
$\ln Y_{i}=\beta_{o}+\beta_{2} \ln X_{1 i}+\beta_{3} \ln X_{2} i+\beta_{4} \ln X_{3 i}+\beta_{5} \ln X_{4 i}+\beta_{6} \ln X_{5 i}+\beta_{7} \ln X_{6 i}+\beta_{8}$

$$
\ln \mathrm{X}_{7 \mathrm{i}}+\beta_{9} \ln \mathrm{X}_{8 \mathrm{i}}+\beta_{10} \ln \mathrm{X}_{9 \mathrm{i}}+\beta_{11} \ln \mathrm{X}_{10 \mathrm{i}}+u_{\mathrm{i}}
$$

Where $\mathrm{Y}=$ output value of vegetables in $\mathrm{kg}$ per ha

$\mathrm{X}_{1}=$ Land input (ha)

$\mathrm{X}_{2}=$ Labour input (hours/ha)

$\mathrm{X}_{3}=$ Organic manure input $(\operatorname{cost} / \mathrm{kg})$

$\mathrm{X}_{4}=$ Irrigation water input (cost/plot)

$\mathrm{X}_{5}=$ Seeds input $(\operatorname{cost} / \mathrm{kg})$

$\mathrm{X}_{6}=$ Soil preparation input (cost/ha)

$\mathrm{X}_{7}=$ Age of farmer (years)

$\mathrm{X}_{8}=$ Children in organic farming (number)

$\mathrm{X}_{9}=$ Experience (years)

$\mathrm{X}_{10}=$ Educational level (number of years of education)

$\mathrm{X}_{11}=$ Farm entity $(1=$ owned, $2=$ rented $)$

where $\beta_{\mathrm{o}}=\ln \beta_{1}$ in equation 3 .

The model is linear in the parameters $\beta_{\mathrm{o}}, \beta_{1}, \beta_{2}, \beta_{3}, \beta_{4}, \beta_{5}, \beta_{6}, \beta_{7}, \beta_{8}, \beta_{9,} \beta_{10}$ and $\beta_{11}$ and is therefore a linear regression model. The statistical hypotheses used are $\mathrm{H}_{1}: \beta=0$ and $\mathrm{H}_{0}$ : otherwise. If it is found that $\beta$ is significantly greater or less than zero, the null hypothesis, $\mathrm{H} 0$ : $\beta=0$, can be rejected ant it can be concluded that the variable impacts the production of organic vegetables. A positive (negative) parameter estimate $(\beta)$ suggests a higher (lower) likelihood of an increase in organic vegetable production.

\section{Results and Discussion}

This section discusses the results analyzed using the Statistical Package for the Social Sciences program (SPSS). The return to scale efficiency and Cobb- Douglas production function analyses were performed. The analysis covered the linear regression model expressed in equation 3. The regression results for vegetable production are presented in Table 1.

Table 1. Regression results for vegetable production in Swaziland

\begin{tabular}{|l|l|l|l|c|}
\hline Variable & $\beta$ & Std. Error & \multicolumn{1}{c|}{$\mathrm{t}$-value } & $\mathrm{p}$-value \\
\hline Constant & 0.404 & 0.066 & 6.141 & 0.103 \\
\hline Land $\left(\ln \mathrm{X}_{1}\right)$ & -0.232 & 0.006 & -36.390 & 0.017 \\
\hline Labour $\left(\ln \mathrm{X}_{2}\right)$ & 0.601 & 0.008 & 71.392 & 0.009 \\
\hline Organic manure $\left(\ln \mathrm{X}_{3}\right)$ & 1.704 & 0.018 & 93.042 & 0.007 \\
\hline Irrigation water $\left(\ln \mathrm{X}_{4}\right)$ & -0.035 & 0.022 & -1.592 & 0.357 \\
\hline Seeds $\left(\ln \mathrm{X}_{5}\right)$ & 1.618 & 0.020 & -80.943 & 0.008 \\
\hline Soil preparation $\left(\ln \mathrm{X}_{6}\right)$ & 0.428 & 0.003 & 140.439 & 0.005 \\
\hline Age $\left(\ln \mathrm{X}_{7}\right)$ & 0.678 & 0.009 & 71.551 & 0.009 \\
\hline
\end{tabular}




\begin{tabular}{|l|l|l|l|c|}
\hline Children $\left(\ln \mathrm{X}_{8}\right)$ & -0.653 & 0.013 & -50.269 & 0.013 \\
\hline Experience $\left(\ln \mathrm{X}_{9}\right)$ & 0.046 & 0.010 & 4.713 & 0.133 \\
\hline Education level $\left(\ln \mathrm{X}_{10}\right)$ & -0.741 & 0.008 & -95.070 & 0.007 \\
\hline Farm legal entity $\left(\ln \mathrm{X}_{11}\right)$ & -2.347 & 0.022 & -107.464 & 0.006 \\
\hline
\end{tabular}

$\mathrm{R}^{2}=0.89 ; * * * \mathrm{p} \leq 0.01(1 \%) ; * * \mathrm{p} \leq 0.05(5 \%) ;$ Return to scale $\left.=1.067\right)$

The coefficients of Land $\left(X_{1}\right)$ and Children $\left(\ln X_{8}\right)$ had negative but significant effects at the $5 \%$ level on vegetable production. The results indicated that both land and number of children in the household contributed significantly to vegetable production. Comparing the two coefficients, the number of children in the household contributed more to the production of vegetables than land size.

Education level $\left(\ln \mathrm{X}_{10}\right)$ and Farm legal entity $\left(\ln \mathrm{X}_{11}\right)$ had negative but significant effects at the $1 \%$ level on vegetable production. The results showed that both variables contributed significantly to vegetable production. Comparing the two coefficients, farm legal entity had higher weighting coefficient and contributed more to the production of vegetables than education level. The result indicates that those farmers who rent land are less likely to embark upon organic vegetable production. Studies indicate that rented land compared with full ownership of land is less likely to induce on0farm investment (Anim, 1999). The results showed negative correlation of both variables to the production of vegetables. However the effect of Labour $\left(\ln X_{2}\right)$, Organic manure $\left(\ln X_{3}\right)$, Seeds $\left(\ln X_{5}\right)$, Soil preparation $\left(\ln X_{6}\right)$ and Age $\left(\ln \mathrm{X}_{7}\right)$ was positive and significant at the $1 \%$ level on vegetables production.

This suggested that these variables had a great influence in the production of vegetables. Comparing these five coefficients, organic manure contributed more to the production of vegetables than any other variables. The results also indicated a positive correlation of these variables to the production of vegetables. The results presented that irrigation water $\left(\ln X_{4}\right)$ had a negative effect in the production of vegetables. Experience $\left(\ln \mathrm{X}_{9}\right)$ appeared to have a positive effect in the production of vegetables. As far as the production of vegetables is concerned; the total sum of $\beta_{1}+\beta_{2}+\ldots . \beta_{11}$ of inputs was greater than one (1.067) indicating increasing returns to scale. This suggested that doubling the inputs will more than doubling the outputs.

\section{Conclusions and Recommendations}

\subsection{Conclusions}

The purpose of this study was to investigate the efficient use of resources in organic vegetable production in Manzini region of Swaziland. The results indicated that the use of inputs in the production of vegetables was efficient, and indicated increasing returns to scale.

Organic farming contributes to puts back to earth what Mother Nature deserves and maintain the peace of Mother Nature. Substantially organic farming has supported the levels of biodiversity and proves that levels of abundance and diversity of wild life. Organic agriculture includes all agricultural systems that promote the environmentally, socially and economically sound production of food and fibres. The research design descriptive research design applying to both quantitative and qualitative approach. The research used both secondary and primary data. Secondary data was gathered from various official reports while primary data was 
collected from a cross-sectional survey of organic food producers in the region. A Cobb-Douglas production function in its stochastic form was to analyse the data.

The findings suggested that variables land, labour, organic manure, seeds, soil preparation, age; children, education level and farm legal entity were having significant effect in organic vegetables production in the region. The use of inputs in the production of the vegetables showed increasing returns to scale.

\subsection{Recommensdation}

Given the findings of the study, it is recommended that in order for farmers to produce efficiently; all inputs that were significant to the production of the vegetables were to be doubled which will double the output. Although this study examined several factors that were hypothesised to affect the production of vegetables, further studies will be necessary to identify other socio economic factors that may also affect production of vegetables.

\section{References}

Alvensteben, R. V., \& Altmann, M. (1987). Determinants of the demand for organic food in Germany. Acta Horticulture, 203, 235-243.

Anim, FDK. (2010). Organic vegetable farming in rural areas of the Northern Province. Unpublished paper.

Avery, D. T., \& Avery, A. (2004). Farming to sustain the environment. Hudson Briefing paper no. 190. Indianapolis: Hudson Institute.

Avery, A. (2006). The Truth About Organic Foods (Volume 1, Series 1). Henderson Communications, L.L.C. ISBN 0-9788952-0-7

Bord Bia. (2012). Advertising Activities by Irish State Agency Food Board. Bord Bia Brand. http://www.bordbiabrand.com/Login/?ReturnUrl=\%2f

Davies, A., Titterington, A., \& Cochrane, C. (1995). Who buys organic food?: a profile of purchasers of organic food in Northern Ireland. British Food Journal, 97(10), 17-23. http://dx.doi.org/10.1108/00070709510104303

Dixon, P. L., \& Holmes, J. C. (1987). Organic farming in Scotland. Edinburgh: Edinburgh School of Agriculture.

Egwald Economics. Production functions: Cobb-Douglas. www.egwald.ca/economics/productionfunctions.php

Feber, R. E., Firbank, L. G., Johnson, P. J., \& Macdonald, D. W. (1997). The effects of organic farming on pest and non-pest butterfly abundance. Agriculture Ecosystems and Environment, 64, 133-139. http://dx.doi.org/10.1016/S0167-8809(97)00031-5

Feber, R. E., Bell, J., Johnson, P. J., Firbank, L. G., \& Macdonald, D. W. (1998). The effects of organic farming on surface-active spider (Araneae) assemblages in wheat in southern England, UK. The Journal of Arachnology, 26, 190-202. 
Francis, C., \& J. van Wart. (2009). History of Organic Farming and Certification, in Organic farming: the ecological system. American Society of Agronomy. pp. 3-18

Frieben, B., \& Köpke, U. (1995). Proceedings of the first ENOF workshop: "Biodiversity and Land Use: The Role of Organic Farming”, Bonn, 9-10 Dec. 1995.

Gujarati, DN. (2006). Basic Econometrics. $2^{\text {nd }}$ ed. New York: Bernard M. Baruch College.

Herrera-Estrella, L., \& Alvarez-Morales, A. (2001). "Genetically modified crops: hope for developing countries?". EMBO Reports (The EMBO journal), 2(4), 256-258. http://dx.doi.org/10.1093/embo-reports/kve075

Hutchins, R. K., \& Greenhalgh, L.A. (1997). Organic confusion: sustaining competitive advantage. British Food Journal, 336-338. http://dx.doi.org/10.1108/00070709710193998

Lotter, D. W., Seidel, R., \& Liebhardt W. (2003). The performance of organic and conventional cropping systems in an extreme climate year. American Journal of Alternative Agriculture, 18(3), 146-154. http://dx.doi.org/10.1079/AJAA200345

Lohr, L., \& Park, T. A. (2004). Assessing organic production efficiency: A stochastic distance function approach. A selected paper presented at the Western Agricultural Economics annual meeting held from June 30-July 2, 2004, Honolulu, Hawaii.

Magkos F, Arvaniti, F, \& Zampelas, A, (2006). Organic Food: Buying More Safety or Just Peace of Mind? A Critical Review of the Literature. Critical reviews in food science and nutrition, 46(1), 23-56. http://dx.doi.org/10.1080/10408690490911846

Niemeyer, K, \& Lombard, J. (2003). Identifying problems and potential of the conversion to organic farming in South Africa. Contributed paper presented at the $41^{\text {st }}$ annual conference of the Agricultural Economics Association of South Africa (AEASA)' October 2-3, 2003, Pretoria, South Africa.

Organic Trade Association. (2008). Soil healt. hhttp://www.ota.com/organic/benefits/soil.html

Rigby, D, \& Cacere, D. (2001). Organic farming and the sustainability of agricultural systems. Agricultural Systems, 68(1), 21-40. http://dx.doi.org/10.1016/S0308-521X(00)00060-3

Soil Association. (2000). The Biodiversity Benefits of Organic Farming http://www.soilassociation.org/LinkClick.aspx?fileticket=Xe2yOpM84w0\%3d\&tabid=385

$\begin{array}{llll}\text { Studymode. } & \text { (2011). Organic } & \text { Farming }\end{array}$ http://www.studymode.com/essays/Organic-Farming-811787.html

Tregear, A., Dent, J. B., \& McGregor, M. J. (1994). The demand for organically grown produce. British Food Journal, 94(4), 21-25. http://dx.doi.org/10.1108/00070709410061032

Wandel, M., \& Bugge, A. (1997). Environmental concern in consumer evaluation of food quality. Food quality and Preference, $8(1), \quad 35-40$. http://dx.doi.org/10.1016/S0950-3293(96)00004-3 
Wikipedia.

Cobb-Douglas

production 2014, Vol. 2, No. 2

http://en.wikipedia.org/wiki/Cobb\%E2\%80\%93Douglas_production_function

Writework. (2006). Emergence

Farming.http://www.writework.com/essay/organic-farming

WriteWork. (2012). Organic Farming. http://www.writework.com/essay/organic-farming-1

\section{Copyright Disclaimer}

Copyright for this article is retained by the author(s), with first publication rights granted to the journal.

This is an open-access article distributed under the terms and conditions of the Creative Commons Attribution license (http://creativecommons.org/licenses/by/3.0/). 